\title{
Cellular and Molecular Biology
}

E-ISSN : 1165-158X / P-ISSN : 0145-5680

www.cellmolbiol.org

\section{Original Research \\ Kisspeptin increases intracellular calcium concentration by protein kinase C-mediated signaling in the primary cultured neurons from rat hippocampus}

\author{
Ihsan Serhatlioglu, Hande Yuksel ${ }^{1}$, Emine Kacar $^{2}$, Sibel Ozcan $^{3}$, Sinan Canpolat $^{2}$, Mete Ozcan ${ }^{1 *}$, Ahmet Ayar $^{4}$, \\ Haluk Kelestimur ${ }^{2}$ \\ ${ }^{1}$ Department of Biophysics, Faculty of Medicine, Firat University, Elazig, Turkey \\ ${ }^{2}$ Department of Physiology, Faculty of Medicine, Firat University, Elazig, Turkey \\ ${ }^{3}$ Department of Anesthesiology and Reanimation, Faculty of Medicine, Firat University, Elazig, Turkey \\ ${ }^{4}$ Department of Physiology, Faculty of Medicine, Karadeniz Technical University, Trabzon, Turkey
}

Correspondence to: mozcan@firat.edu.tr,meteozcan@hotmail.com

Received November 8, 2017; Accepted May 15, 2018; Published May 30, 2018

Doi: http://dx.doi.org/10.14715/cmb/2018.64.7.10

Copyright: (C) 2018 by the C.M.B. Association. All rights reserved.

\begin{abstract}
In addition to the fact that kisspeptin and its receptor GPR54 are well known to be abundantly expressed in the hypothalamus with suggestive roles in the initiation of puberty and similar reproductive system properties, there is also proof showing that kisspeptin might have influences on hippocampal functions. In our previous study, it was shown that kisspeptin increased free intracellular $\mathrm{Ca}^{2+}$ values $\left(\left[\mathrm{Ca}^{2+}\right]_{\mathrm{i}}\right)$ through protein kinase $\mathrm{C}$ (PKC) activation in GT1-7 cells. For this reason, we examined the influences of kisspeptin on $\left[\mathrm{Ca}^{2+}\right]_{\mathrm{i}}$ in hippocampal neurons to determine if kisspeptin shows its effects on hippocampus through the same mechanism. Hippocampal neurons were excised from the brains of fetuses on $17^{\text {th }}$ embryonic day from maternal rats. The influences of kisspeptin on $\left[\mathrm{Ca}^{2+}\right]_{\mathrm{i}}$ in hippocampal neurons were examined through in vitro calcium imaging system. The responses of $\left[\mathrm{Ca}^{2+}\right]_{\mathrm{i}}$ to kisspeptin were quantified by the changes in $340 \mathrm{~nm} / 380 \mathrm{~nm}$ ratio. Kisspeptin-10 caused $\left[\mathrm{Ca}^{2+}\right]_{\mathrm{i}}$ transients in hippocampal neurons. The change in $\left[\mathrm{Ca}^{2+}\right]_{\mathrm{i}}$ by $100 \mathrm{nM}$ kisspeptin was prevented by pre-treating the cells in PKC inhibitor chelerythrine chloride. According to the results, kisspeptin activates intracellular calcium signaling in hippocampal neurons via the pathway that depends on PKC. The results of this study suggest that kisspeptin may have a role in hippocampal neuron functions.
\end{abstract}

Key words: Kisspeptin; Calcium; Hippocampus; Protein kinase C; Calcium imaging.

\section{Introduction}

G protein-coupled receptor 54 (GPR54) uses kisspeptins as natural ligands (1-3). GPR54 mutations are related to immaturity in sexual terms, and human and rodent infertility (4-6). It was shown that Gonadotropinreleasing hormone (GnRH) neurons express GPR54 receptor (7), and with this receptor, kisspeptins activate GnRH excretion (8). It was shown that kisspeptins are the most potent activators of hypothalamus-pituitarygonadal (HPG) axis (9). The administration of kisspeptin in a chronic central way to immature female rats induced a premature gonadotrophic axis activation (10), and peripheral kisspeptin injection increased plasma levels of luteinizing hormone (LH) at a significant level (11).

Even though the peptide and peptide receptor GPR54 are plenty in the hypothalamus and are considered to be associated with puberty initiation and similar functions of the reproductive system, there is also proof that kisspeptin might have important influences on hippocampal activities. In the hippocampus, the density of GPR54 is extremely high in the dentate gyrus (DG) granule cell layer. Metastin, also called kisspeptin, is suggested to potentiate excitatory synaptic transmission reversibly in hippocampus (12), which makes us think that the kisspeptin-GPR54 system may have selective functions in the hippocampus. In the previous study of ours (13), we demonstrated that kisspeptin increases free intracellular $\mathrm{Ca}^{2+}\left(\left[\mathrm{Ca}^{2+}\right]_{\mathrm{i}}\right)$ through protein kinase $\mathrm{C}$ (PKC) activation in hypothalamic GT1-7 immortalized cell lines. For this reason, in this study, the influences of kisspeptin on $\left[\mathrm{Ca}^{2+}\right]_{\mathrm{i}}$ were examined in the neurons in the hippocampal area to determine if kisspeptin shows its influences on hippocampus through the same mechanism. Since much of neural development occurs during fetal stages of life, and neurogenesis is limited in adult brain, we measured $\left[\mathrm{Ca}^{2+}\right]_{i}$ in fetal hippocampal neurons, using calcium imaging system.

\section{Materials and Methods}

Preparation of culture of rat hippocampal neurons

All animal use procedures were approved by the Firat University Animal Experiments Local Ethics Committee and rats were treated in accordance with the national and international laws and policies on the care and use of laboratory animals. Hippocampal neurons were isolated from $17^{\text {th }}$ embryonic day (E17) from Sprague-Dawley maternal rats. Prenatal pups were removed from the uterus of maternal rats after intraperitoneal anesthesia with $10 \%$ chloral hydrate $(1 \mathrm{~mL} / 250 \mathrm{~g}$ body weight). Then animals were decapitated to remove brain tissue under a dissecting microscope on ice using sterile scissors and forceps. Brain hemispheres were separated, and remove the midbrain using forceps in order to ex- 
pose the hippocampus. Hippocampus was dissected from the cortex using finer scissors and cleaned off the meninges. Then the hippocampal tissue was carefully chopped and then mechanically dissociated through trituration by using flame-narrowed Pasteur pipette.

Hippocampal cells were then plated on to $12 \mathrm{~mm}$ round, poly-D-lysine/laminin-coated glass coverslips (BD BioCoat, Bedford, MA, USA) and bathed in Neurobasal-A medium (Gibco, Paisley, Scotland), supplemented with 2\% B27 (Gibco), 1\% Glutamax (Gibco), and penicillin $(5000 \mathrm{IU} / \mathrm{mL})$ streptomycin $(5000 \mu \mathrm{g} /$ $\mathrm{mL}$ ).

Hippocampal neurons were kept in a humidified incubator containing $95 \%$ air and $5 \% \mathrm{CO}_{2}$ at $37^{\circ} \mathrm{C}$ (HeraCell, Heraeus, Germany). The cells were used 6 hours after the plating up to 24 hours in culture.

\section{Ratiometric intracellular calcium imaging}

Hippocampal neurons were treated with dye that was sensitive to calcium fura-2/AM ester in recording solution for 60 minutes. After washing out the dye-containing medium for 3-4 times with recording solution, the cells were used for image analysis. The recording solution had (in mM): 5.0 glucose, $0.6 \mathrm{MgCl}_{2}, 10.0$ HEPES, $3.0 \mathrm{KCl}, 1.0 \mathrm{NaHCO}_{3}, 2.0 \mathrm{CaCl}_{2}$ and $130.0 \mathrm{NaCl}$. The recording system had inverted Nikon TE $2000 \mathrm{~S}$ microscope (S-fluor, 40X oil, 1.3 NA) and CCD camera (ORCA 285, Hamamatsu Photonics, Hamamatsu, Japan). $340 \mathrm{~nm}-380 \mathrm{~nm}$ excitation filters and $510 \mathrm{~nm}$ emission filter were used during recording. Fluorescence ratio of cells was determined by using the imaging software (simple PCI). Results were computed as mean peak amplitude from at least three independent experiments. Effect of kisspeptin on intracellular calcium values was normalized and expressed as percentage change from the baseline calcium level $(100 \%)$.

There was no effect on $\left[\mathrm{Ca}^{2+}\right]$, when administered alone in the control experiment of Fura-2AM dissolved in DMSO.

\section{Statistical analysis}

The data were given as mean \pm SEM values. Effects of kisspeptin $(10,30$ and $100 \mathrm{nM})$ on calcium levels were determined analyzed by One-Way Analysis of Variance (ANOVA) and then Post-Hoc Tukey HSD test was also applied. The influences of protein kinase $\mathrm{C}$ inhibitor chelerythrine chloride on kisspeptin induced $\left[\mathrm{Ca}^{2+}\right]_{\mathrm{i}}$ levels were assessed with unpaired Student's ttest. $\mathrm{P}<0.05$ was taken as significant.

\section{Results}

Kisspeptin dose-dependently increased intracellular $\mathrm{Ca} 2+$ transients in hippocampal neurons. Fig. 1 shows that the mean peak amplitude data of $\left[\mathrm{Ca}^{2+}\right]_{\mathrm{i}}$ increase evoked by kisspeptin was significantly and dosedependently to $104.4 \pm 3.6(\mathrm{n}=31, \mathrm{p}<0.01), 111.6 \pm 3.9$ $(\mathrm{n}=34, \mathrm{p}<0.01)$ and $141.2 \pm 4.1 \quad(\mathrm{n}=42, \mathrm{p}<0.01)$ from baseline level after application of $10 \mathrm{nM}, 30 \mathrm{nM}$ and 100 nM kisspeptin, respectively.

The ability of the protein kinase $\mathrm{C}$ inhibitor (chelerythrine chloride) to influence the $\left[\mathrm{Ca}^{2+}\right]_{\mathrm{i}}$ response to kisspeptin $(100 \mathrm{nM})$ was also investigated. As shown in Fig2, peak $\left[\mathrm{Ca}^{2+}\right]_{\mathrm{i}}$ response to kisspeptin $(100 \mathrm{nM})$ was
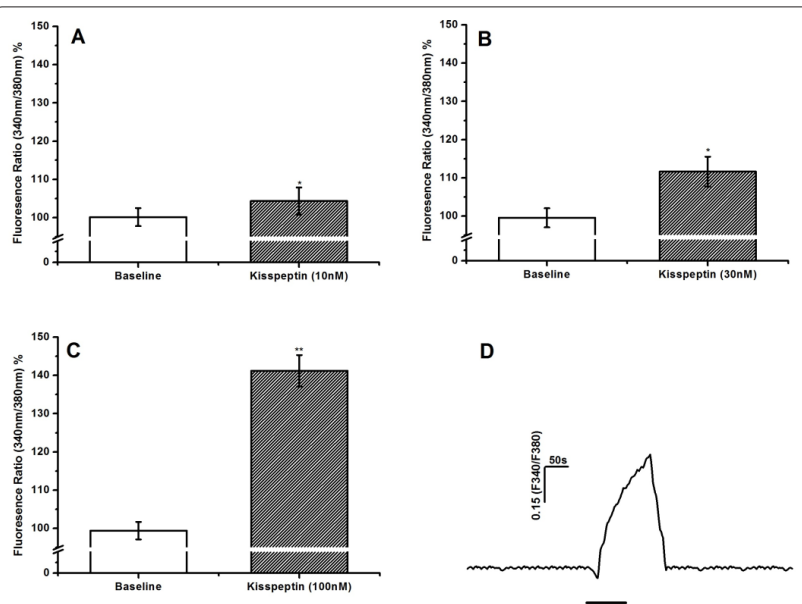

D

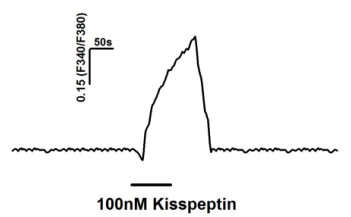

Figure 1. The effects of kisspeptin on intracellular calcium levels in hippocampal neurons. A) $10 \mathrm{nM}$ kisspeptin $(\mathrm{n}=31)$, B) 30nM kisspeptin $(n=34)$ and C) $100 n M$ kisspeptin $(n=42)$ stimulated $\mathrm{Ca}^{2+}$ responses in different hippocampal cells, D) original responses trace of fluorescence ratio to $100 \mathrm{nM}$ kisspeptin application from one hippocampal neuron. Single asterisk $(*) p<0.01$ and double asterisks $(* *) p<0.001$ vs control (one-way analysis of variance and post-hoc Tukey HSD test) from three independent experiments.

strongly attenuated to $107.4 \pm 4.6 \%(\mathrm{n}=42, \mathrm{p}<0.001)$ after adding $10 \mu \mathrm{M}$ PKC inhibitor (Fig. 2).

\section{Discussion}

We have found that intracellular calcium signaling in hippocampal neurons is activated by kisspeptin. This shows that kisspeptin has new roles in hippocampal functions. Whereas in our previous study (13), it was found that there was a kisspeptin-stimulated intracellular calcium response in a triphasic pattern in GT1-7 cells which are immortalized GnRH neurons, kisspeptin10-induced $\left[\mathrm{Ca}^{2+}\right]$ i response in the hippocampal neurons was in a different pattern (Fig. 1), suggesting the presence of functional kisspeptin receptors in these cells as well. Although there are many studies suggesting an important role of kisspeptin in hippocampal functions (1416), molecular mechanisms are not well known. There is only one study (17) looking at the effects of kisspeptin on intracellular calcium concentration in hippocampal neurons to date. At that study, the brains of the 4-6 day

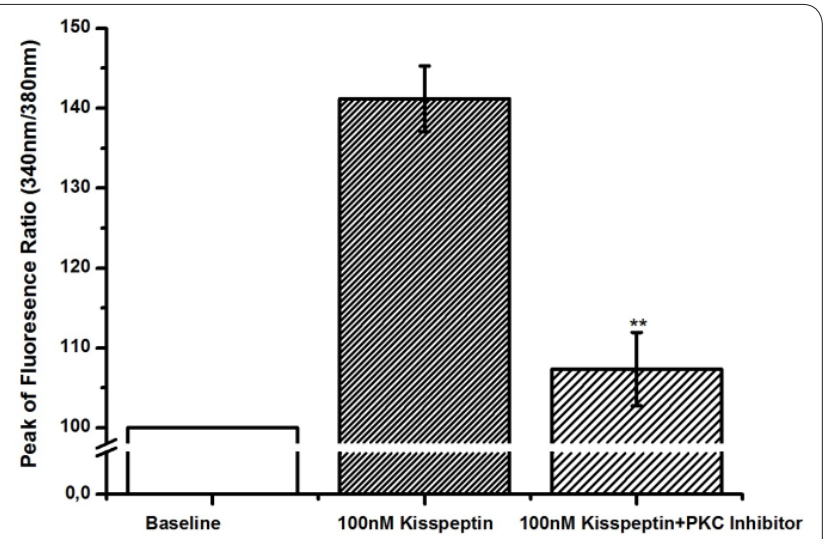

Figure 2. The effect of PKC inhibition on $100 \mathrm{nM}$ kisspeptinstimulated intracellular calcium rise in hippocampal neurons. * $\mathrm{P}<0.001$ vs $100 \mathrm{nM}$ kisspeptin (unpaired $t$ test) from three independent experiments. 
newborn rats were used to culture the hippocampal neurons, and an increase of $\left[\mathrm{Ca}^{2+}\right]_{i}$ was seen in only 6 of the 40 cultured hippocampal neurons. In our study, hippocampal neurons were taken from fetal brains removed on E17 from maternal rats, and almost all the neurons responded to kisspeptin. Several factors may underline in the different findings between the study of Brailoiu et al. (17) and ours. One difference is that we used kisspeptin-10 whereas they used metastin or kisspeptin-54. A 145 -amino acid polypeptide $(\mathrm{Kp}-145)$ is the primary translation product of the KiSS-1 gene (3), but shorter 'kisspeptins' with 10, 13, 14 or 54 amino acid residues have been discovered, and are termed kisspeptin-10, $-13,-14$ and -54 according to number of amino acids in length. The decapeptide kisspeptin-10 (shared by all the members of kisspeptin family) is necessary for biological activity (1). Kisspeptin-54, also termed 'metastin', is the putatively secreted and biological active form of kisspeptin-145 (18). Our study shows that kisspeptin-10 is more effective compared to metastin at least in terms of effects on $\left[\mathrm{Ca}^{2+}\right]_{i}$ in the hippocampal neurons. Interestingly, only kisspeptin-10, but not other kisspeptins increased $\left[\mathrm{Ca}^{2+}\right]_{\text {in }}$ in isolated first trimester trophoblasts (19), invasion of which is a key process for successful reproduction and embryonic development. Thus, kisspeptin-10 seems to increase $\left[\mathrm{Ca}^{2+}\right]_{\mathrm{i}}$ more effectively not only in fetal brains but also in fetal peripheral tissues. Secondly, the differences in $\left[\mathrm{Ca}^{2+}\right] \mathrm{i}$ response to kisspeptin may result from the use of the hippocampal neurons obtained from the brains at different ages. We used 17 day fetuses whereas Brailoiu et al. (17) used 4-6 day newborn rats. Thus, it can be speculated that kisspeptin may be more effective prenatally compared to its postnatal effects. Whether the different effectiveness of prenatal and postnatal kisspeptin is related to receptor sensitivity remains to be clear.

Although it was found that kisspeptins could increase intracellular calcium ions, there is no knowledge concerning the mechanisms by which kisspeptin exerts its effects on $\left[\mathrm{Ca}^{2+}\right]_{i}$. In our study, we determined that calcium-enhancing influence of kisspeptin-10 was blocked by PKC inhibitor, chelerythrine chloride. These outcomes show that enhancement of $\left[\mathrm{Ca}^{2+}\right]_{i}$ by kisspeptin-10 involves the PKC pathway in a specifically manner. Our results are consistent with the findings that inhibitors of phospholipase C (PLC) and PKC abolished the regulation of the tested genes transcriptionally-regulated through intracellular calcium release in the human MDA-MB-435S cell line originating from a metastatic ductal breast carcinoma (20).

There were several limitations in this study. First, we used short term culture protocol. The development of axonal and dendritic extensions of hippocampal cells may affect fluorescence calcium imaging calculations. So, neurons were used 6 hours after the plating up to 24 hours in culture. Secondly, it was too difficult to determine the effects of kisspeptin on specific hippocampal regions such as CA1, CA2, CA3 and dentate gyrus because of use of prenatal cells.

Our findings first time demonstrated that kisspeptin increased $\left[\mathrm{Ca}^{2+}\right]_{\mathrm{i}}$ via PKC mechanism in hippocampal neurons. Kisspeptin may have a role in hippocampal neuron functions. The understanding of the kisspeptin$\mathrm{Ca}^{2+}$ signaling pathway associated with learning and memory processing may establish the novel therapeutic strategies for neurodegenerative disorders.

\section{Acknowledgements}

This study was supported by Turkish Scientific Technical Research Organization (TUBITAK Project No: 114S179).

\section{Interest conflict}

The authors declare there is no conflict of interest with regard to data presented in this article.

\section{Author's contribution}

İ.S, HY, E.K, SO; experimentation,

S.C, A.A; Experiment design

M.O; Statistical analysis and manuscript preparation

A.A, H.K; Experiment design and manuscript preparation.

\section{References}

1. Kotani M, Detheux M, Vandenbogaerde A, Communi D, Vanderwinden JM, Le Poul E, et al. (2001) The metastasis suppressor gene KiSS-1 encodes kisspeptins, the natural ligands of the orphan Gprotein coupled receptor GPR54. J Biol Chem 2001; 276: 34631.

2. Muir AI, Chamberlain L, Elshourbagy NA, Michalovich D, Moore DJ, Calamari A, et al. AXOR12, a novel human G protein-coupled receptor, activated by the peptide KiSS-1. J Biol Chem 2001; 276: 28969-75.

3. Ohtaki T, Shintani Y, Honda S, Matsumoto H, Hori A, Kanehashi $\mathrm{K}$, et al. Metastasis suppressor gene KiSS-1 encodes peptide ligand of a G-protein-coupled receptor. Nature 2001; 411: 613-7.

4. de Roux N, Genin E, Carel JC, Matsuda F, Chaussain JL, Milgrom E. Hypogonadotropic hypogonadism due to loss of function of the KiSS1-derived peptide receptor GPR54. Proc Natl Acad Sci U S A 2003; 100: 10972-76.

5. Seminara SB. Kisspeptin in reproduction. Semin Reprod Med. 2007; 25(5):337-43.

6. Funes S, Hedrick JA, Vassileva G, Markowitz L, Abbondanzo S, Golovko A, et al. The KiSS-1 receptor GPR54 is essential for the development of the murine reproductive system. Biochem. Biophys. Res Commun 2003; 312: 1357-63.

7. Parhar IS, Ogawa S, Sakuma Y. Laser-captured single digoxigenin-labeled neurons of gonadotropin-releasing hormone types reveal a novel G protein-coupled receptor (GPR54) duringmaturation in cichlid fish. Endocrinology 2004; 145: 3613-18.

8. Messager S, Chatzidaki EE, Ma D, Hendrick AG, Zahn D, Dixon $\mathrm{J}$, et al. Kisspeptin directly stimulates gonadotropin-releasing hormone release via G protein-coupled receptor 54. Proc. Natl Acad Sci USA 2005; 102: 1761-66.

9. Han SK, Gottsch ML, Lee KJ, Popa SM, Smith JT, Jakawich SK, et al. Activation of gonadotropin-releasing hormone ( $\mathrm{GnRH})$ neurons by kisspeptin as a neuroendocrine switch for the onset of puberty. J Neurosci 2005; 25: 11349-56.

10. Navarro VM, Fernández-Fernández R, Castellano JM, Roa J, Mayen A, Barreiro ML, et al. Advanced vaginal opening and precocious activation of the reproductive axis by KiSS- 1 peptide, the endogenous ligand of GPR54. J Physiol 2004; 561: 379-86.

11. Thompson EL, Patterson M, Murphy KG, Smith KL, Dhillo WS, Todd JF, et al. Central and peripheral administration of kisspeptin-10 stimulates the hypothalamic-pituitary-gonadal axis. J Neuroendocrinol 2004; 16: 850-8.

12. Arai AC, Xia YF, Suzuki E, Kessler M, Civelli O, Nothacker HP. Cancer metastasis-suppressing peptide metastin upregulates excit- 
atory synaptic transmission in hippocampal dentate granule cells. J Neurophysiol 2005; 94: 3648-52.

13. Ozcan M, Alcin E, Ayar A, Yilmaz B, Sandal S, Kelestimur H. Kisspeptin-10 elicits triphasic cytosolic calcium responses in immortalized GT1-7 GnRH neurones. Neurosci Lett 2011; 492: 55-8. 14. Jiang JH, He Z, Peng YL, Jin WD, Wang Z, Han RW, et al. (2015) Kisspeptin-13 enhances memory and mitigates memory impairment induced by $A \beta 1-42$ in mice novel object and object location recognition tasks. Neurobiol Learn Mem 123: 187-95.

15. Telegdy G, Adamik Á. The action of kisspeptin-13 on passive avoidance learning in mice. Involvement of transmitters. Behav Brain Res. 2013; 243:300-5.

16. Arai AC. The role of kisspeptin and GPR54 in the hippocampus. Peptides. 2009; 30(1): 16-25.
17. Brailoiu GC, Dun SL, Ohsawa M, Yin D, Yang J, Chang JK, et al. KiSS-1 expression and metastin-like immunoreactivity in the rat brain. J Comp Neurol 2005; 481: 314-29.

18. Harms JF, Welch DR, Miele ME. KISS1 metastasis suppression and emergent pathways. Clin Exp Metastasis 2003; 20: 11-8.

19. Bilban M, Ghaffari-Tabrizi N, Hintermann E, Bauer S, Molzer S, Zoratti C, et al. Kisspeptin-10, a KiSS 1/metastin-derived decapeptide, is a physiological invasion inhibitor of primary human trophoblasts. J Cell Sci 2004; 117: 1319-28.

20. Yoon MJ, Lee AR, Jeong SA, Kim YS, Kim JY, Kwon YJ, et al. Release of $\mathrm{Ca} 2+$ from the endoplasmic reticulum and its subsequent influx into mitochondria trigger celastrol-induced paraptosis in cancer cells. Oncotarget. 2014; 5(16):6816-31. 